Migration Studies - Review of Polish Diaspora nr 3 (173)/2019, http://www.ejournals.eu/Studia-Migracyjne/

10.4467/25444972SMPP.19.032.11074

\title{
Migration Crises and Interest of a State. American Refugee Assistance Acts During the Cold War
}

\author{
ANNA MAZURKIEWICZ1 \\ Uniwersytet Gdański
}

\begin{abstract}
The article examines the link between the admission of refugees to the United States and the country's foreign policy interest during the Cold War. The author analyses the post-war American refugee assistance acts and immigration laws to reveal U.S. policy choices made between safeguarding country's security during the Cold War to taking political advantage of the refugee arrivals. The factors that provided for the refugees' entry to the U.S. during the Cold War were determined by foreign policy concerns and the decisions related to the refugee crises were the domain of the executive up until 1980s. Given the Cold War context, most of the refugee crises occurring behind the Iron Curtain in Europe benefited U.S. psychological warfare programs, while Asian and Latin American refugees, often a consequence of direct (at times covert) U.S. political-military-economic involvement, put the U.S. on the defensive.
\end{abstract}

Keywords: Refugee, quota system, Cold War, migration, displaced persons, boat people, resettlement, anti-Communism

Looking at the United States as a country of immigrants which - as Donna Gabaccia writes - is problematic even to the Americans themselves ${ }^{2}$ - produces an impression of the country's openness to diversity, multiculturalism, social justice. However, the history of the United States is one of both "shining, golden opportunity" as novelist Thomas Wolfe once wrote "...to every man, regardless of his birth [...] the right to live, to work, to be himself, and to become whatever thing his manhood

\footnotetext{
1 Contact: anna.a.mazurkiewicz@ug.edu.pl

2 Donna Gabaccia, Foreign Relations. American Immigration in Global Perspective (Princeton, Oxford: Princeton University Press, 2012), 153-158.
} 
and his vision can combine to make him" ${ }^{3}$ as well as one of exclusion, segregation and rejection.

From the dawn of American history numerous groups of refugees from Europe sought safe haven on the other side of the Atlantic Ocean. Beginning with the unfortunate travelers onboard Mayflower, more often than not, refugees heading to the American shores had economic interests in mind. After all, the Pilgrims' lives were not threatened in Holland - they had left for the British colonies overseas for both ideological and economic reasons. Almost half of those onboard who were heading to Virginia (and ended up in Plymouth) were investors, entrepreneurs with solely economic aims in mind ${ }^{4}$.

Refugees or immigrants? Throughout American history the terms were blurred in social, economic history as well as in the country's laws. Examining the reasons and circumstances surrounding the refugee arrivals to the American shores of Quakers, Mennonites, Catholics, French Revolutionaries of late $18^{\text {th }} \mathrm{C}$, and the German 48ers, the Irish fleeing the famine - all these groups could have been called "refugees". The term, however, would also be most suitable to describe the fate of displaced Native Americans, fugitive slaves, people leaving the U.S. for Liberia, or Canada (in the course Indian Wars of the nineteenth century as well as even during the Vietnam War in the twentieth). While not the subject of this paper, the issue of the "American refugee" is worth further investigation ${ }^{5}$.

This text focuses on the examination of the connection between the admission of refugees to the United States and the country's immigration policies. Ideally, this should be analyzed in three consecutive phases. The first should cover the period from first naturalization laws of 1790, through immigration reforms that took place since 1870s, leading to the creation of the Bureau of Immigration in 1891. The second phase would cover the great migration of the turn of the centuries. As U.S. continued to admit refugees among the "huddled masses yearning to breathe free" ${ }^{\text {, }}$, the term itself bore no legislative connotation?. By mid-1930s any refugee arrivals to the U.S., as no such category existed, were guarded by the immigrant quota laws of 1921, 1924. While not

3 Thomas Wolfe, You Can't Go Home Again (New York: Scribner, 2011), 432. This book was first published in 1940, copyright 1934.

${ }^{4}$ Bhu Srinivasan, Americana. A 400-Year History of American Capitalism (New York: Penguin Press, 2017), 10-17.

${ }^{5}$ The opening case could be one of the "Great Expulsion" of Acadians. David W. Haines, Safe Haven. A History of Refugees in America (Sterling, VA: Kumarian Press, 2010),

6 Citation from Emma Lazarus' "The New Colossus" - a sonnet engraved at the pedestal of the Statue of Liberty in 1903 which re-defined the meaning of liberty goddess to one of a "mother of exiles" welcoming ships with immigrants from Europe. The Statue of Liberty- Ellis Island Foundation, Inc. https:// www.libertyellisfoundation.org/the-new-colossus [accessed: 29 III 2019].

7 Although special cases, like the Mexican Revolution, prompted special entry permits based on "humane considerations". U.S. Citizenship and Immigration Services, https://www.uscis.gov/history-andgenealogy/our-history/refugee-timeline [accessed: 29 III 2019]. For a general survey (1870s to World War II) see: Guarded Gate, 4-17. 


\section{SM̂PP}

present in the U.S. immigration laws, the term "refugee" entered international relations arena with Fridtjof Nansen's efforts to help mostly Russian and Armenian refugees (via League of Nations) ${ }^{8}$. American (failed) efforts at international coordination in regard to Jewish refugees date back to the Franklin D. Roosevelt's presidency ${ }^{9}$.

While the American quota system severely limited the possible number of immigrant arrivals, only 5\% of the German quota was used in 1933; 42\% in 1937 and the 1939 quota was used to bring to America the Germans from Cuba and Great Britain. At the same time $\mathrm{m} / \mathrm{s}$ St. Louis carrying the Jewish refugees from Nazi Germany was not received by either Cuba, United States nor Canada. Moreover, the U.S. Congress rejected the Wagner-Rogers Act of 1939 providing for the reception of 20,000 kids from Germany ${ }^{10}$. However, some preliminary changes began to occur following the fall of France. A program was devised to provide for the entry of about 2 thousand German political exiles and intellectuals stuck in France. Upon careful selection 1,200 were let in in 1940; and 800 in 1941 ${ }^{11}$. Furthermore, in 1943 a hundred and seven visas were issued for the Chinese (to emphasize the alliance with the Kuomintang ${ }^{12}$ ) and in 1944 FDR admitted 987 Jewish refugees from the camps in Italy ${ }^{13}$. To be admitted, they had to meet the traditional immigration criteria: could not become a liability to the society (federal budget), had to find support of an American citizen (vouchering for their moral conduct), had to be cleared in terms of former political affiliations and evaluated as to potential contribution to the United States.

It was not until the Convention relating to the Status of Refugees adopted by the United Nations in 1951 that the definition of a refugee was agreed upon internationally ${ }^{14}$. Interestingly, the U.S. did not sign the UN Convention of 1951, but only the 1967 Protocol on Refugees (in 1968), incorporating the UN definition of a refugee in the Refugee Act of 1980. Therefore, in the American context, as proposed by David Haines, the dark decade of migrations (mid-1930s-mid-1940s) was an era of noninvention of a refugee ${ }^{15}$.

This study focuses on the third phase immediately following the Second World War which was responsible for the greatest refugee crisis the world had seen to that

8 Gilbert Jaeger, "On the history of the international protection of refugees," (International review of the Red Cross) RIRC 83/843 (September 2001): 727-736, https://www.icrc.org/en/doc/assets/files/ other/727_738 jaeger.pdf [accessed: 28 III 2019]

9 Evian Conference (1938) convened at Roosevelt's initiative.

10 Haines, 2-3; Guarded Gate..., 17-26.

11 Carl J. Bon Tempo, Americans at the gate: The United States and Refugees During the Cold War (Princeton University Press, 2008), 18-19.

${ }^{12}$ Chinese nationalist forces led by Chiang Kai-Shek supported by the United States against Japan but also Chinese Communists led by Mao Tse Tung.

${ }^{13}$ Gabaccia writes that this was the first case of American president using "parole". Gabaccia, 146.

${ }^{14}$ Convention and Protocol relating to the Status of Refugees (UNHCR: Geneva 2010), https:// www.unhcr.org/en-us/protection/basic/3b66c2aa10/convention-protocol-relating-status-refugees. html [accessed: 29 III 2019]; Gabaccia, 216-217.

15 Haines, 3. 
point. While migration and foreign affairs overlapped since the dawn of U.S. history, Eva Szabo also points to the American involvement in World War II to mark the beginning of country's immigration policy becoming a "major tool for furthering the national interest"16.

The era of the Cold War (Truman to Reagan administrations) marks American rise to global power, U.S. economic, political and strategic interests located further and further away from constituents selecting the country's government. It also denotes the era of ideological struggle in which the "hearts and minds" of people across the globe were to be won over by words as much as economic and military operations. In a bipolar world, refugees crossing over to the other side could become both a liability and an asset. Both key adversaries - Washington and Moscow - used refugees to advance their own interests. Since only one of them was a democratic regime susceptible to voters' decisions, this analysis offers a look at the American refugee policies only. The aim of this paper is to show the foreign policy interest of the state in refugee legislation. To what extent did the Cold War confrontation warrant the American responses to refugee crises? Was ideology a factor in refugee admissions? How were the refugee admissions negotiated between the executive and legislative branches, between foreign and domestic policy concerns? This study results from my earlier research on American policies towards East and Central European exiles during the early years of the Cold War $^{17}$. Hereby employing comparative perspective (that is looking at refugees from other countries of the world until 1980s), I look at the post-war American refugee assistance acts and immigration laws with an aim of demonstrating U.S. policy choices made between safeguarding country's security during the Cold War to taking political advantage of the refugee arrivals.

The groundbreaking act providing assistance to postwar refugees was issued by president Truman on December 22, 1945 in the form of an executive order. It provided for the arrival of 40,000 DPs giving preference to victims of Nazi persecution who were in U.S. zones of occupation. This provision was taken at the expense of the quotas and therefore it should be considered as a preference given to the refugees rather than an increase in the number of people admitted to the U.S. It was expanded in 1946 by the War Brides Act (120,000 spouses and children of U.S. military personnel) and by including Chinese and Japanese immigrants in $1947^{18}$. Refugee laws mixed with immigration regulations. Laws regulating immigration were effectively circumvented by the executive.

Presidential decision of 1945 and the relatively small number $(40,000)$ requires a more thorough attention as it marks not only "the invention of a refugee" but also

${ }^{16}$ Eva Eszter Szabo, Migration as a tool for U.S. Foreign Policy in the Cold War, Hungarian Review 10/2, 17 V 2017, http://hungarianreview.com/article/20170517_migration_as_a_tool_of_us_foreign_policy_in_the_cold_war

${ }_{17}$ Anna Mazurkiewicz, Uchodźcy polityczni z Europy Środkowo-Wschodniej w amerykańskiej polityce zimnowojennej 1948-1954 (Warszawa-Gdańsk: IPN, 2016).

18 Uchodźcy..., 122-123. 


\section{SM̂PP}

the beginning of political uses of these. For example, among the DPs that Truman wished to admit there were refugees from the three Baltic states whose annexation by the Soviet Union was not recognized by American government. Deportation of the "Baltic Boat people" - refugees who had already come to America's shores in yachts purchased and equipped in Sweden - was ruled out by the Department of State. Two issues overlapped in this case: anti-Communism and the U.S. policy which proclaimed non-recognition of the Soviet seizure and forcible incorporation to the USSR of the Baltic States. Moreover, the DP Act of 1948 providing for the admission of 205,000 DPs contained a clear preference for the Balts. Up to November 1950 - based on the provisions contained in both DP Acts - close to 217,000 visas were issued of which 60.5 thousand were allotted to the Balts. At the time the relevant quota for these countries were: 116 for Estonia, 236 for Latvia, and 386 for Lithuania. However, the DPs Acts maintained the refugee admission rates as a credit towards the quotas for individual countries. So, in the case of Estonia the "quota debt" (if quota for the country should remain unchanged) would have been paid by 2086; Latvia - by 2152; and Lithuania by the year 2054'19. Upon Truman's insistence, the DP Act was amended in 1950 and the refugee admission rules were liberalized. The number to be admitted increased to 400,000 . The United States continued to accept DPs from Europe from October 30, 1948 to July 21, 1952. All the newcomers had to have individual sponsors providing job and housing, all had to undergo security screening.

American security concerns related to aliens are as old as the country itself. It was already in 1797 that Harrison G. Otis (Representative from Massachusetts) called for closing of the gates ${ }^{20}$. From the Alien and Sedition Laws of 1798 to restrictions of World War I, Japanese internment in 1942, Americans were concerned with security breaches posed by "foreigners". The Immigration and Naturalization Service (INS) was established in 1933. In June 1940 the INS was moved from the Department of Labor to the Department of Justice which signaled the change in perception of migration from an economic to security issue. While visas remained within the prerogatives of the Department of State (foreign policy), the fear of disloyalty, strict control over aliens were subjected to the law enforcement agencies. This coincided with the adoption of the Foreign Agents Registration Act of 1938 (amended in 1942), the Smith Act of 1940 and McCarran Act of 1950 which provided for closer monitoring, visa denial and deportation of people who were considered a danger to public order ${ }^{21}$.

Many political exiles, escapees and defectors were not included in the DP numbers listed above and came to the U.S. under special provisions. During the Cold War the following terms can be used to describe different categories of people fleeing their

19 Uchodźcy..., 123.

20 Norman L. Zucker, Naomi Flink Zucker, Desperate Crossings, Seeking Refuge in America (New York: Routledge, 2015), 12.

21 Uchodźcy..., 122-124 
homes due to some form of coercion: displaced persons, emigres, expellees, escapees, defectors, asylum seekers, special entrants (an ad hoc arrangement, confers the right to remain in the U.S. but does not lead to citizenship), parolees, non-returnees, EVDs (extended voluntary departure groups, people who cannot go back since the situation at home changed, their return is unsafe $)^{22}$.

Many of the formerly prominent political leaders from countries seized by the Communists entered the U.S. on business, tourist, transit or diplomatic visas. American plans for their utilization for Cold War political warfare programs were ready by early months of $1948^{23}$. However, in just few years since their arrival, their original status expired, and many were also stripped of their citizenship and thus lost their passports. What made their situation even more complex was that they rejected naturalization for political reasons (to continue their political mission on behalf of their homelands). In order to avoid deportation, the political exiles looked for ways to secure their permanent residence in the U.S. One path was to file an affidavit (immediately stopping deportation procedure) and then apply for change of status (become DPs while already in the U.S.). Another solution was to ask any member of the Congress for a private bill. In the case of absence of personal contacts, insufficient access by ethnic groups, facilitating such high-level contact was the Free Europe Committee ${ }^{24}$. This American prime Cold War asset, state-private organization willing to utilize the exile potential, actively assisted the selected persons, offering legal and political assistance to the "alien associates". Finally, an exile could give in and file naturalization papers which many equaled to loosing agency and legitimacy of political activities in exile.

In 1952 the McCarran-Walter Act (known officially as INA, Immigration and Nationality Act) changed U.S. immigration law providing, for the first time, for three visa categories: non-immigrant, immigrant and for asylum seekers (refugees). Yearly quota was established for the refugees with allotments for parts of the world in accordance "with the special humanitarian interest of the United States"25. At the time, such wording could have been interpreted as assistance addressed to anti-Communists. In the early 1950s the Cold War divide had already produced a significant impact on American policy (foreign and domestic), electoral strategies, even on national

22 Normal L. Zucker, Naomi Flink Zucker, The Guarded Gate. The Reality of American Refugee Policy (San Diego, New York, London: Harcourt Brace Jovanovich Publishers, 1987), xiv-xvi; Mazurkiewicz, "Unwilling Immigrants: Transnational Identities of East Central European Exiles during the Cold War," Studia Migracyjne-Przegląd Polonijny 4 (158), (2015): 159-171; Haines, 89.

${ }^{23}$ Katalin Kadar Lynn, "At War While at Peace: United States Cold War Policy and the National Committee for a Free Europe, Inc.", in: The Inauguration of Organized Political Warfare. Cold War Organizations sponsored by the National Committee for a Free Europe/Free Europe Committee, ed. Katalin Kadar Lynn (Saint Helena, CA: Helena History Press, 2013), 17-21.

24 The same organization was responsible for organizing broadcasts of Radio Free Europe. Uchodźcy..., 179-258.

${ }^{25}$ Guarded Gate..., 29-30; Gabaccia, 147. The act included small number of visas for refugees. It authorized the Attorney General to issue parole but only on emergency basis. 


\section{SM̂PP}

identity. Hence the emergence of the "American Nationalist Globalism" - which John Fousek explains as the mixture of anti-Communism, American convictions of global responsibility and American greatness giving it the right "to lead the free world" 26 . Migration laws were not immune from these changes. The INA carried a provision from the McCarran's Act of 1950 which made it almost impossible for any Communist, former Communist, or a Communist sympathizer to obtain a permit to settle in the U.S. ${ }^{27}$ While the Act eliminated racial barriers to immigration, it did maintain regional limits in the form of the so-called Asian Pacific Triangle. It also expanded the provisions allowing the U.S. government to deport individuals (immigrants and naturalized citizens) for anti-state activities.

Moreover, the Immigration and Nationality Act of 1952 carried one particularly interesting, yet often overlooked provision of "parole". Under special circumstances, the attorney general (the head of the Department of Justice) could issue a special permit to admit for any foreigner he deemed "in the American national interest" (also for any medical or legal reasons). Originally intended to be used on case by case basis, this provision was used mostly to let in people coming from the Communist-dominated countries. In 1957 it was first used en masse to accept over 30,000 Hungarians who did not get into the U.S. under the provisions of the Refugee Relief Act of 1953 (about 6,000) nor under the Refugee-Escapee Act of $1957^{28}$. This provision was further expanded in the INA of 1965, which proved particularly useful in the Cuban case. The anti-Communists fleeing the island could hope for a special entry permit, or for conversion of their tourist visas (or visa waivers). Parole gave them the right to work (not all professions were accepted) but it was not a path toward American citizenship ${ }^{29}$.

All in all, the 1953 Act provided for the admission of 205,000 people escaping from Communism (non-quota visas), by 1954 expanded it by additional 24,000. The act was administered by the State Department and not INS (of the Justice Department) ${ }^{30}$.

In early 1957 American goals in the Middle East were redefined on the basis of the Eisenhower Doctrine ${ }^{31}$. Following the Suez Crisis, the president evidently denoted this region as another Cold War battlefield offering economic and military

26 John Fousek, To Lead the Free World: American Nationalism \& The Cultural Roots of the Cold War (Chapel Hill: University of North Carolina Press, 2000), 1-2, 15.

27 Americans at the Gate, 27-32.

${ }^{28}$ In 1958 on the basis of Hungarian Refugee Adjustment Act these parolees could become permanent citizens. Similar was the latter case with Cubans (Cuban Status Adjustment Act of 1966). In 1962 -1979 mass parole was applied to Cubans, in 1975-1980 to Indochinese. Guarded Gate..., 32, 55; Szabo; Gabaccia, 148.

29 Juan M. Clark, The Exodus from Revolutionary Cuba (1959-1974). A Sociological Analysis (PhD Dissertation, University of Florida 1975), 73, 111, http://www.latinamericanstudies.org/book/Clark-PhD-1975. pdf [accessed: 28 III 2019]. Over the 15 years that Clark examined parolees were $64.2 \%$ of all arrivals.

30 Guarded Gate, 31.

31 January 5, 1957: Eisenhower Doctrine, University of Virginia Miller Center, Transcript https://millercenter.org/the-presidency/presidential-speeches/january-5-1957-eisenhower-doctrine [accessed: 29 III 2019]. 
assistance to countries facing Communist threat. Soon, the Refugee-Escapee Act of 1957 followed with special provisions for refugees from the countries or the Middle East $^{32}$. These were in line with 1953 Act but established a separate category for the refugees, outside of the quota system.

The 1953 and 1957 acts were the first to be dedicated to the Cold War refugees and - over the years - they provided for the admission of exiles from both Europe and Asia (among them: Italians from Trieste, expelled Germans, Yugoslavs, Greeks, Poles from Great Britain but also Iran and Indonesia). Section 2(a) of the 1953 Refugee Relief Act defined the refugee as: "any person in a country or area which is neither Communist nor Communist-dominated, who because of persecution, fear of persecution, natural calamity or military operations is out of his usual place of abode and unable to return thereto, who has not been firmly resettled, and who is in urgent need of assistance for the essentials of life or for transportation". The act also singled out "escapees" (2(b)) "any refugee who, because of persecution or fear of persecution on account of race, religion, or political opinion, fled from the Union of Soviet Socialist Republics or other Communist, Communist-dominated or Communist-occupied area of Europe including those parts of Germany under military occupation by the Union of Soviet Socialist Republics, and who cannot return thereto because of fear of persecution on account of race, religion or political opinion" ${ }^{\prime 3}$. While the first and the last require little explanation, the emergence of a special category of an "escapee" calls for a comment.

Already in 1952, the Eisenhower administration implemented the U.S. Escapee Program. This was a major, publicly announced plan that called for utilizing anti-Communist refugees. It should be considered a supplement to an earlier idea presented in 1950 by Massachusetts senator Henry Cabot Lodge who advocated formation of military exile units within the U.S. Army. While he envisioned over two thousand soldiers, the strict recruitment criteria provided for the enlistment of... 113 men within the first year of the program ${ }^{34}$. Given the hostile attitude of the Pentagon the project was doomed. By 1953 also the CIA-led covert operations with the use of the exiles in Europe, including paramilitary, proved to be a complete failure. The only programs developed in partnership with the East European exiles developed between the CIA and the Department of State that seemed to bear fruit were in the form of Radio Free Europe and free world propaganda. For the American public and its representation in Congress it seemed however that not much was being done.

Therefore, when the Mutual Security Act was presented in Congress in October 1951 (offering 7.5 billion dollars for economic, military and technical support

32 Daniels, 126-128; Americans at the Gate..., 82-83.

33 Gil Loescher, John A. Scanlan, Calculated Kindness: Refugees and America's Half-Open Door, 1945 to the Present (New York: Free Press, 1986), 45-46; Refugee Relief Act of 1953, U.S. Statues at Large, Public Law 203, chapter 336, 400-407, https://loveman.sdsu.edu/docs/1953RefugeeReliefAct.pdf [accessed 30 III 2019]. 


\section{SM̂PP}

of America's allies), senator Kersten decided to amend it with a provision to allot 100 million dollars to sponsor exile military force. His initiative caused panic among those in the CIA and State Department who had been sponsoring clandestine operations for years and already knew all too well that these were compromised and not effective (interestingly no one seemed to recall these failures by 1961 when the Bay of Pigs was carried out). The so-called Kersten Raider posed a grave danger of the sensational information being revealed to the U.S. public. While this was prevented, once the money was allotted by Congress it had to be spent somehow. Lodge was able to convince Eisenhower that Volunteer Freedom Corps should be created (only to fade away years later), while Kersten became convinced by psychological strategy planners that the 100 million dollars he secured in Congress would be used best if allocated to assisting refugees in Europe ${ }^{35}$. These operations were to include inducing new escapes from the Soviet Bloc and confronting Soviet propaganda which claimed that the West had neglected the refugees living in dire conditions in the camps since the end of World War II. In fact, both much publicized (and largely failed) initiatives constituted a tip of an iceberg of U.S. programs designed to utilize the potential of Cold War refugees.

The immigration acts of mid-1950s which encompassed anti-Communist refugees were intended to assist humanitarian crisis but also to exploit the fact of dramatic escapes from Soviet-dominated regions for propaganda purposes, utilize the potential of the political exiles, as well as induce new escapes. Early in the Cold War Americans realized that migration form the Communist-dominated bloc constituted a great opportunity for the development of psychological warfare programs, but it needed attention, funds and long-term planning. Refugee policy was used as one of the many fronts of Cold War confrontation. After all, encouraging defections by key civilian and military personnel with security information or specialized knowledge was a great way to disrupt the Soviet administration, and to drain it of talent to the benefit of U.S. intelligence. In Europe, encouraging risky escapes which included crossing heavily militarized borders of the Soviet bloc bore little potential of inducing mass migration that could pose major problem to Americans. At the same time, risking death or imprisonment if caught in order to live "in the free world" provided excellent news.

On the other side of the iron curtain, the Soviets were aware of the propaganda value of migrants disaffected by capitalism, especially if properly dramatized. Hence, it was not surprising to see the "repatriation campaign" unveiled by the Soviets in 1955. What was surprising, was the scale of its success in luring refugees residing in the West to return to their homelands ${ }^{36}$. Over the next decades returns of prominent political exiles dispelled the notion of lethal threat posed by Communism, validated the Soviet claims of post-Stalinist thaw, and disrupted the political émigré

\footnotetext{
35 Uchodźcy..., 410-413, 419-423, 429-430.

${ }^{36}$ Uchodźcy..., 467-468.
} 
communities in the West. Not surprisingly the Americans agitated the émigrés to counteract re-emigration which they referred to as re-defection ${ }^{37}$.

As the Cold War spread into other regions of the world, so did the challenge of re-defection. Already in 1953, the U.S. suffered a stunning propaganda blowback when the 23 young soldiers decided not to come home after the end of the fighting in Korea. Their decision to go to Communist China instead was a tough lesson to the Americans psywar planners (namely Psychological Strategy Board). Despite the much celebrated 22,000 prisoners of war from North Korea (mostly Chinese, but former Kuomintang) who were turned into refugees assisted in relocating to Taiwan, the 23 young men seeking refuge in a Communist country were a propaganda disaster. Especially that Communists were broadcasting messages recorded by the Western non-returnees describing the evils of: "KKKism, McCarranism and McCarthyism" as reasons not to return to the U.S. ${ }^{38}$ Here too, the Free Europe Committee facilitated useful services by its East Central European exile associates to prepare and disseminate information intended for Asian audiences warning them of the evils of Communism.

The Korean War (1950-1953), the first Indochina War (1946-1954) both generated significant refugee crisis. In both cases, just like in divided Germany, the coerced migrants were largely absorbed by the part of the divided state that was supported by the United States. By the end of the decade, most of the Cold War refugees resided on other continents separated from the U.S. by the Oceans. Therefore, their reception model usually encompassed transitional stages of application, verification (often awaiting the results in a refugee camp), followed by admission and resettlement procedures. Americans pledged their devotion to the ideals engraved at the pedestal of the Statue of Liberty from a safe distance, employing elaborate mechanisms to separate people whom they were willing to admit. The sudden arrival by the sea of the Baltic refugees in 1940s - given their relatively small number, ethnic origin, and the incidental nature, was not considered a breach in otherwise safeguarded shores. This changed dramatically with the victory of the Castro-led forces in Cuba. Less than 150 kilometers away, Cubans who supported the pro-American regime of Fulgencio Batista sought refuge in Miami and beyond.

While the tradition of Cuban freedom fighters crossing the sea to the United States looking for support, arms and men goes back to the $19^{\text {th }}$ century ${ }^{39}$, the Cuban

${ }^{37}$ ACEN memorandum on the organization of the refugee world for the fight against the new Soviet plan for peaceful conquest of the world and for counter-acting the Communist repatriation campaign. Attachment to: Secretary general ACEN to General Committee, 5 III 1956, Immigration History Research Center (IHRC), Assembly of Captive European Nations (ACEN), 62/5; Adam Niebieszczański, Responsibility of the Communist regimes and their organs for crimes against the peoples of captive nations, 15 V 1956, IHRC, ACEN, 62/5.

38 Susan L. Carruthers, Cold War Captives. Imprisonment, Escape, and Brainwashing (Berkeley, Los Angeles, London: University of California Press, 2009), 174-216.

39 Jose B. Fernandez, "Following the Trial of Major General Carlos Mialofsky in the United States," in: Diaspora polska w Ameryce Północnej, ed. Rafał Raczyński, Katarzyna Morawska (Gdynia: Muzeum 


\section{SM̂PP}

boat lifts that followed the initial anti-Communist escapee waves were unprecedented. The Castro regime skillfully played the Americans by releasing democratic oppositionists, alongside with criminals and mentally disabled people to cause havoc and anti-immigrant sentiment in the U.S. ${ }^{40}$ In 1962 the Migration and Refugee Assistance Act was adopted followed by the Cuban Refugee Program implemented by the Kennedy administration. Since the breaking of the diplomatic relations (3 January 1961) the Cubans in the U.S. were entitled to apply for "parole" 212(D)(5) of INA and were often granted the status of indefinite voluntary departure, IVD. After the boat (and air) lifts of Varadero (1965), Camarioca (1965-71), Mariel (1980) the Americans learned that unprepared for the life-threatening arrivals as they were, this crisis could only be resolved by negotiation with the sending regime. Bill Clinton in 1994 decided to confine the Cuban boat peoples in Guantanamo and negotiate with Castro the admission of not more than 20,000 Cubans a year. However, this was after the collapse of the American arch-enemy, the USSR, so in a different ideological context.

All in all, from 1945 to 1965 the United States received 700,000 refugees. High as this number may seem, one must note that at the very same time it accepted five million immigrants, and this was just the opening of a brand-new era initiated by the Hart-Celler Act in 1965 which removed the quota system and allotted regional limits for immigration. For twenty years U.S. refugee policy resulted from responses to certain crises and were of temporary character. In 1965, the immigration laws incorporated the refugee admissions which amounted to less than $10 \%{ }^{41}$. It also maintained the way for the executive power to use the "parole" mechanism to admit desired groups of refugees ${ }^{42}$. From 1948 to 1974 the single largest group admitted to the U.S. outside of the immigration laws (as refugees or special entrants) were Cubans (47\%; arrivals were counted since 1959). 30\% of refugees were the postWorld War II DPs, followed by those admitted under the Refugee Relief Act (15\%). The "parolees" of the years 1965-1974, that is since Hart-Celler Act, constituted $6 \%$. The least numerous groups among the refugees admitted since 1948 were the Hungarians who came in the aftermath of the 1956 Revolution $(2 \%)^{43}$.

By 1968 when the Hart-Celler Act was implemented the immigration patterns changed for good ${ }^{44}$. Interestingly, that same year the United States signed the 1967 Protocol amending the 1951 UN Convention relating to the Status of Refugees (which the U.S. did not sign at the time). As the protocol expanded the definition of a refugee, the United States had finally joined the international community in uniform definition and recognition of refugee status. This also meant that the U.S.

40 Clark, 108-116.

41 Szabo; Gabaccia, 172, 179-180.

42 Roger Daniels, Guarding the Golden Door. American Immigration Policy and Immigrants since 1882 (New York: Hill and Wang, 2004), 129-146.

43 Haines, 4.

${ }^{44}$ U.S. Census Bureau, How do we know? America's Foreign Born in the Last 50 Years, https://www. census.gov/content/dam/Census/library/visualizations/2013/comm/foreign-born.png [accessed: 29 III 2019 ]. 
was bound by the "non-refoulement" principle ${ }^{45}$. However, separated from the Cold War confrontation sites (direct refugee flows) by two oceans, Americans were rarely the first country to grant asylum. Moreover, the country's laws still did not include the broad UN definition.

In the context of the Cold War, neither the Baltic yachts of the 1940s nor the Cuban "boat lifts" that started in 1960 gave the name to the term "boat people". This one was reserved to a major migration crisis that followed the end of the American war in Vietnam (1975), Vietnam's war with Kampuchea, and then with China in 1979. In order to assist the humanitarian crisis caused by these conflicts which resulted, among others, in the persecution of the Chinese living in Vietnam, Jimmy Carter introduced Migration and Refugee Assistance Act of 1975. It provided for the admission of the 130,000 refugees from Vietnam, Cambodia and Laos. It was complemented by the Indochinese Refugee Assistance Program allotting special funds (just like in the case of Cubans) for the resettlement projects.

By 1979 one more refugee-centered program was introduced: Foreign Operations Appropriation Act designed for the purpose of resettling refugees from the USSR and "other countries currently not a subject of other refugee assistance programs". Since these programs proved to be very costly, the U.S. government decided to allow NGO and private partnership within Agency Matching Grant Program. It provided for a fifty-fifty co-sponsorship of refugees by the foundations, religious and ethnic organizations. Regardless, the anti-Communism remained the key principle leading refugee assistance policy.

The process of evolution of American laws regarding refugee reception during the Cold War capped with the adoption of the Refugee Act of 1980 which incorporated the UN convention's definition of a refugee into U.S. law ${ }^{46}$. In title I of the said act (sec. 101, a) it proclaimed:

The Congress declares that it is the historic policy of the United States to respond to the urgent needs of persons subject to persecution in their homelands, including, where appropriate, humanitarian assistance for their care and maintenance in asylum areas, efforts to promote opportunities for resettlement or voluntary repatriation, aid for necessary transportation and processing, admission to this country of refugees of special humanitarian concern to the United States, and transitional assistance to refugees in the United States. The Congress further declares that it is the policy of the United States to encourage all nations to provide assistance and resettlement opportunities to refugees to the fullest extent possible ${ }^{47}$.

45 Donald M. Kerwin, The Faltering US Refugee Protection System: Legal and Policy Responses to Refugees, Asylum Seekers, and Others in Need of Protection (Migration Policy Institute: Washington, 2011), 2, https://www.migrationpolicy.org/research/faltering-us-refugee-protection-system [accessed: 28 III 2019].

${ }^{46}$ Refugee Act of 1980, Public Law 96-212, 17 III 1980, https://www.govinfo.gov/content/pkg/

47 Refugee Act of 1980. 


\section{SM̂PP}

This act provided legal basis and stablished explicit procedures on "admission of refugees of special humanitarian concern to the United States, and to provide comprehensive and uniform provisions for the effective resettlement and absorption of those refugees who are admitted". Hence a uniform and effective resettlement and absorption policy was created in the form of the US Refugee Admission Program (USRAP) which replaced the Interagency Committee on Refugee Affairs created under Carter in 1979, and which now included:

- Office of Refugee Resettlement (ORR), within the Department of Health and Human Services,

- Bureau of Population, Refugees and Migration (PRM), under the care of the Department of State;

- U.S. Citizenship and Immigration Services (USCIS), U.S. Department of Homeland Security, domestic and foreign NGOs.

The act 1980 recognized the already existing office of U.S. Coordinator for Refugee Affairs (appointed by president, confirmed by Senate).

Furthermore, with this act, the UN definition of a refugee was introduced into American legal code, broadening the pre-existing descriptions:

The term refugee 5 means:

(A) any person who is outside any country of such persons nationality or, in the case of a person having no nationality, is outside any country in which such person last habitually resided, and who is unable or unwilling to return to, and is unable or unwilling to avail himself or herself of the protection of, that country because of persecution or a well-founded fear of persecution on account of race, religion, nationality, membership in a particular social group, or political opinion, or

(B) in such special circumstances as the President after appropriate consultation may specify, any person who is within the country of such person's nationality or, in the case of a person having no nationality, within the country in which such person is habitually residing, and who is persecuted or who has a well-founded fear of persecution on account of race, religion, nationality, membership in a particular social group, or political opinion.

The term 'refugee' does not include any person who ordered, incited, assisted, or otherwise participated in the persecution of any person on account of race, religion, nationality, membership in a particular social group, or political opinion"48.

With this new definition, the Americans adopted the concept of a refugee without geographic or ideological boundaries. They added a category (b) of refugees who could not leave their own homeland, while the phrase relating to natural disasters 
present in the 1965 Act disappeared. ${ }^{49}$ The act recognized the right to ask for asylum, which recognized the rights of these refugees who were already in the U.S.

In 1965 the limit on number of refugees was set at 17,400 per year. With 1980 Refugee Act Congress wished to reassert control over refugee admissions (repeatedly circumvented since president Johnson). The Congress effectively took away the power to deal with migration crises away from the U.S. president. Should the president wish to provide for the admission of more than 50,000 refugees, the Congress consent was since required. The 50,000 was a flexible numerical ceiling. It was subject to annual consultations between the executive branch and the legislature.

The idea behind the act was to "carry out humanitarian ideal to which [this nation] was historically committed [...] the offer of liberty and safety to persons from other lands who are persecuted." The author of these words admitted that the Act has fallen short of achieving its central and most noble goal. In the post-Mariel context, the author assessed that the refugee assistance programs stimulated even more immigration flows. "Foreign policy interests and objectives drove our refugee program out of proportion to the humanitarian purposes envisioned by the Act" Regardless of the wording, ideology and geography, not solely humanitarian impulses continued to guide American policy on refugees. When suggesting the numbers on refugee admissions ("of special humanitarian concern") the Department of State for consultations with the Congress the Worldwide Priorities System was developed. It consisted of six priorities. The highest category applied to people whose lives were in danger, and to political prisoners (compelling concern/interest). Categories 2 and 4 applied to people who had links to the United States (worked for government, any U.S. organization or business). Numbers 3 and 5 concerned people with family in the U.S. The least importance was assigned to specified regional groups whose admissions were in the national interest. Some regions of the world - like Eastern Europe and Soviet Union - fit in all six priorities, while refugees from Latin America and Caribbean would match only categories 1 and $2^{51}$. The fiscal year presentations by the Department of State continued on annual basis. Clearly, the American policy towards refugees continued to mirror American foreign policy goals.

Since the adoption of the Refugee Act 1980, the refugee admissions increased significantly. $41 \%$ of all Cold War refugees arrived in the last decade of this era. All in all, during the Cold War the U.S. admitted 2,471,628 refugees/asylees (terms used

${ }^{49}$ Compare to 1953 Act: person feeling persecution, natural calamity or military operations; 1957 Act: victims of racial, religious, political persecution, fleeing from Communist, Communist-occupied, Communist-dominated or middle East; 1965 - note ideological and geographic restrictions, as well as presence of "uprooted by natural disasters". Guarded Gate..., xvii, 51-52.

50 Doris M. Meissner, "The Refugee Act of 1980: What have we learned?" Revue Européenne des Migrations Internationales 6/1 (1990): 129-131. https://www.persee.fr/doc/remi_0765-0752_1990_ num 6_1_1231 [access: 29 III 2019].

51 Since 1982 - special program for Poles $(3,000)$. Guarded Gate..., 73, 76-77. 


\section{Refugee/Asylee Admissions 1946-1990}

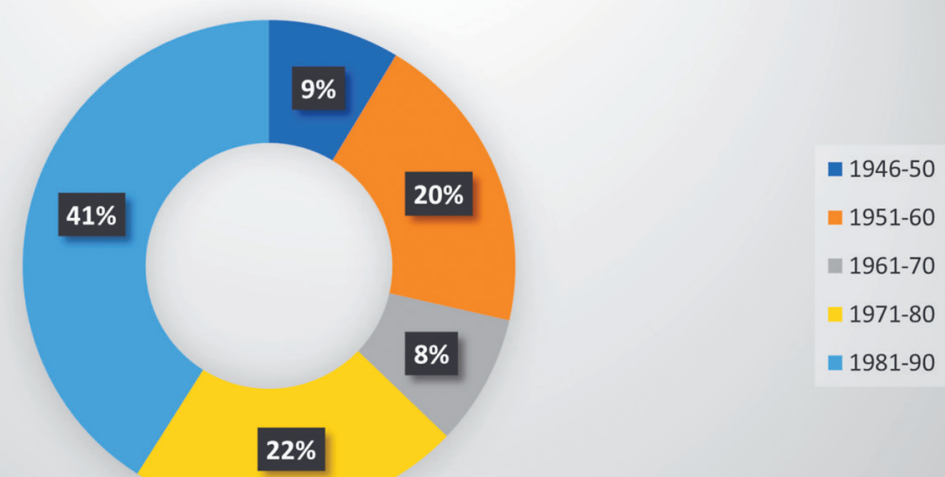

by INS) ${ }^{52}$. However, this does not include special entrants (for example some of the Cuban marielitos), "undocumented entrants" (like Haitians) responsibility for whom was shifted to Federal Emergency Management Agency (FEMA) ${ }^{53}$.

These trends continued in the following decades. From 1975 to 2009 under the U.S. Refugee Admissions Program (USRAP) 48\% of refugees came from Asia, $21 \%$ from Soviet Union (countries of former Soviet Union), 10\% from Eastern Europe, $8 \%$ from Africa and the same number form the Near East, while only $4 \%$ from Latin America ${ }^{54}$.

The extent to which foreign policy dictated responses to refugee streams coming from countries like Guatemala (coup 1954, 30 years of civil war 1960-1996); Salvador (civil war 1980-1982), ma być: Nicaragua (Contra War 1981-1990)) is revealing. In accordance with the U.S. law, since 1980, the refugee must prove that he/she has well-founded reasons to fear return to his/her homeland. The American policy south of Mexico provides ample evidence of the U.S. government supporting oppressive regimes on the sole grounds of their anti-Communist stance. In practice, for the refugees from the countries allied with the U.S. it meant slim chances of being granted a refugee status. After all, how can you support the regime and accept refugees fleeing its grip at the same time? The alternative way to deny refugee status to people from Latin America was to claim they must me economic migrants because their path most commonly leads through Mexico where their lives are no longer threatened. If not economic migrants, they could be presented as dangerous radicals, revolutionaries,

\footnotetext{
52 Daniels, 191.

53 Guarded Gate..., 67-71.

54 Haines, 4
} 
possibly even Communists. It wasn't until 1997 that the law was introduced during Clinton's administration providing for "green cards" to certain Nicaraguans, Cubans, Salvadorans, Guatemalans and nationals of former Soviet bloc countries and their dependents who otherwise would not qualify to stay in the U.S.

Even before the current migration crisis, 88\% of Latin American refugees resided either in the U.S. or in Mexico (500-700 thousand in Mexico, about a million in the U.S.). Yet when one looks at the origin of refugees admitted to the U.S. since 1975, Latin Americans continue to be the least numerous group, almost indiscernible when compared with Asians (peak in 1980s), then Europeans (peak in 1990s) or most recently with Africans ${ }^{55}$. One aspect escaping common purview is that refugees classified as parolees, or economic migrants became invisible in refuge related statistics. With instability and tensions rising south of Rio Grande, without the Cold War dichotomy to employ, the only land migration path leading to the United States is currently the subject of most heated debate and coercive policy employed by the current administration.

Currently the United States maintains world's largest refugee resettlement program, but it does not mean that it is a leader of resettling the largest numbers of refugees. Two thirds of world refugees remain in Asia, Africa and in the Middle East. Most of the refugees in the U.S. are asylum seekers or illegal immigrants who seek protection (refugee status) only after they get into the country. The alternative way to get in is to seek "in-country processing" within the Orderly Departure Program (ODP). However, coming to the United States as a refugee is the most complex way and obtaining the status is extremely difficult and lengthy process. In accordance with the Standard Federal Refugee Resettlement Program it takes up to two years and multiple screenings, checks and interviews ${ }^{56}$ - an elaborate system that was not used even during the hottest moments of the Cold War.

In sum, the factors that provided for the refugees' entry to the U.S. during the Cold War can be arranged in three blocs - foreign policy, domestic policy and the international community pressures on the U.S. Without a doubt, the American policy toward the refugees was determined by foreign policy concerns. The decisions related to the refugee crises were the domain of the executive up until 1980s. Given the Cold War context, most of the refugee crises occurring behind the iron curtain in Europe benefited U.S. psychological warfare programs, while Asian and Latin American refugees, often a consequence of direct (at times covert) U.S. political-military-economic involvement, put the U.S. on the defensive.

55 The Shifting Origins of Refugees to the U.S. Over Time, PEW Research Center, 22 IX 2015 , https://www. pewresearch.org/fact-tank/2015/09/24/how-the-u-s-compares-with-other-countries-takingin-refugees/ft_15-09-23_refugeetousbyregion-2/ [accessed: 29 III 2019].

${ }^{56}$ Infographic: The Screening Process for Refugee Entry into the United States, The White House, 20 XI 2015, https://obamawhitehouse.archives.gov/blog/2015/11/20/infographic-screening-process-refugee-entry-united-states [accessed: 29 III 2019]. 
Factors shaping American refugee policies during the Cold War

\begin{tabular}{|l|l|l|}
\hline International community & \multicolumn{1}{|c|}{ Domestic policy } & \multicolumn{1}{|c|}{ Foreign policy } \\
\hline $\begin{array}{l}\text { Political crises, relations } \\
\text { with enemy states }\end{array}$ & Legal system, red tape & $\begin{array}{l}\text { Psychological/political warfare } \\
\text { programs (military, civil) }\end{array}$ \\
\hline $\begin{array}{l}\text { Supporting friendly } \\
\text { governments }\end{array}$ & $\begin{array}{l}\text { Government domestic } \\
\text { propaganda in support } \\
\text { of U.S. foreign policy }\end{array}$ & Presidential leadership \\
\hline UNHRC, NGOs & $\begin{array}{l}\text { Public opinion } \\
\text { (humanitarian, economic } \\
\text { concerns, ethnic } \\
\text { sentiments) / Congress }\end{array}$ & $\begin{array}{l}\text { Military and/or intelligence } \\
\text { foreign operations }\end{array}$ \\
\hline
\end{tabular}

All in all, the examination of American policies toward refugees during the five decades Cold War leads to the following observations;

Given the peculiar Cold War divided world, the American reaction to the migration crises was a mixture of moral concerns (protection of foreign allies, enemies of the imposed regimes), contemporary political needs (both in foreign and domestic policy), global engagement, international cooperation and resulting humanitarian obligations.

At the same time, it must be underscored that until 1980s no comprehensive plan was in place, hence no strategy to deal with migration/refugee crisis existed. Each was treated as incident and actions were taken in response to it. Therefore, their examination reminds one of chronicles of fallen regimes (say in South East Asia) rather than organized policy with a clearly defined aim $^{57}$.

Moreover, legal reaction to the Cuban crisis or the uprisings and crises in the Eastern Bloc in Europe prove that the U.S. was reactive being forced to respond rather than taking the lead in administering the coming of yet another wave of people forced to leave their homes.

This is, however, not to say that the U.S. had no plan of how to utilize certain desired migrant resources. Which is another way to say that as long as the coerced migrants were useful, their utilization was swift - so the policy was not addressed to the humanitarian crises but to particular groups of refugees who were of interest to the U.S. foreign policy goals.

Can the American experience with refugee resettlement be used in the face of the current migration crisis - largest since the end of World War II? In 2017, for the first time since 1980 U.S. resettled fewer refugees than the rest of the world ${ }^{58}$. Yet, the

57 Haines, 5-6.

58 Phillip Connor, Jens Manuel Krogstad, For the first time, U.S. resettles fewer refugeed than the rest of the world, PEW Research Center, 5 VII 2018, https://www.pewresearch.org/fact-tank/2018/07/05/ for-the-first-time-u-s-resettles-fewer-refugees-than-the-rest-of-the-world/ [access: 29 III 2019]. 
United States remains a preferred place of resettlement of contemporary world refugees. While the countries of the European Union and Canada enjoy better reputation for refugee treatment (humanitarian aid and social security) the myth of the U.S. as the land of opportunity (the American dream) clearly prevails $5^{59}$. Since 1980, decisions regarding refugee admissions were redirected towards the U.S. Congress, steered away from the president (which should be interpreted as a shift from foreign to domestic policy concerns). Without proper ideological base to replace anti-Communism, mindful of the domestic economic agenda dominating public opinion polls, it became more difficult both to respond to international humanitarian crises and to engage desired groups of exiles. In the era of American global involvement, refugee policies are ruled by domestic concerns.

It is to be expected that the interests of the state shall remain at the center of American refugee policies. Defining them, however, poses an unprecedented challenge at the perilous time when global leadership is needed and not global withdrawal. 